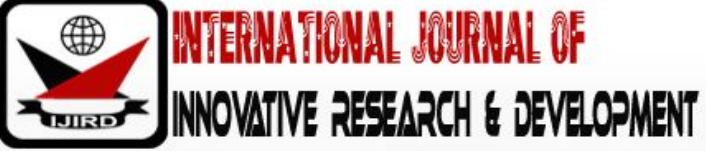

ISSN 2278 - 0211 (Online)

\section{Impact of Consumer Price Index and Gross Domestic Saving on Economic Growth in Sri Lanka: An Econometric Analysis Using Johansen Co-Integration Approach}

\begin{tabular}{|c|} 
Haalisha Aboobucker \\
Assistant Lecturer, Department of Mathematical Sciences, \\
South Eastern University of Sri Lanka, Sri Lanka \\
Dr. A. Jahufer \\
Senior Lecturer, Department of Mathematical Sciences, \\
South Eastern University of Sri Lanka, Sri Lanka
\end{tabular}

\begin{abstract}
:
An essential goal for any developing country like Sri Lanka is to attain high economic growth. Although there are many factors that affect economic growth (GDP), this paper mainly focuses on Consumer Price Index (CPI) and Gross Domestic Saving (GDS) in Sri Lanka, based on the annual time series data for the period of 1960 - 2016 obtained from the Annual Report of World Bank Economic Indicators and Annual Report of Central Bank of Sri Lanka. The Augmented Dickey Fuller unit root test was employed to check the stationarity among the three variables (GDP, CPI, and GDS). The existence of cointegration of the variables was ensured by the Johansen Co-integration test and then the short-run or long-run association among the variables was assessed by Vector Error Correction (VEC) test. The causal relationships among the variables were checked using Granger Causality test. The empirical findings of this study reveal that all the variables have unit root problem at level, but become stationary after first differencing. The results of Johansen Co-integration tests indicate one cointegration equation while the VEC test recommends no short-run relationship among the variables whereas the existence of a long-run relationship. Correspondingly Granger causality test exhibits a unidirectional causality movement from GDP to GDS. Model adequacy tests were implemented on the residuals of the VECM remarks that there is no heteroscedasticity, no serial correlation, and are normally distributed signifying that the model is good enough. This study satisfies an eminent necessity of how CPI and GDS supportive for economic growth.
\end{abstract}

Keywords: Gross domestic product, consumer price index, co-integration, vector error correction model, Sri Lanka

\section{Introduction}

One of the important contributors to economic growth is Gross domestic product (GDP). The GDP is a monetary measure of the market value of all final goods and services produced in a specific period of time. Contemporary, the Sri Lankan economy has revealed a robust raising trend with per capita GDP reaching almost $\$ 4,000$. Sri Lankan government has been implementing privatization and an open economy for worldwide competition which inspiring overseas investments from 1977. Resulting to the controlling of the leftist Janatha Vimukhti Peramuna (JVP), reforms and privatization attained a major enhancement and strain on growth due to export additionally aided in refreshing the performance of economy accelerating GDP growth attains to 7\% in 1993. Some of the major international companies have realised the growth potential of Sri Lanka and made huge investments. In the subsequent years the Sri Lankan economy observed many disturbances resulting in irregular growth of economy but the overall mean yearly GDP growth was at $5.2 \%$ in 1999-2000.However, after independence, the first reduction in GDP was negative 1.4 in 2001.A sequence of universal and national economic complications such as terrorist assaults within Sri Lanka and international influences smashed the economy. The end of year 2001, the political managements was reformed by the parliamentary elections, that the Freedom Party of Sri Lanka retained the Premiership. After the alteration in administration the country acquired a progressive improvement in the economy. The economy profited from lower interest rates from 2002 to 2004,retrieval in domestic demand, improved tourist arrivals, a restoration of the stock exchange, and amplified foreign direct investment. Economic growth reached $4 \%$ in 2002, aided by strong sector growth. The recommencement of the civil war in 2005 directed to a sudden increase in security expenses. However, the economy began to grow in the year 2010 at an advanced rate of 8.0\% as per the civil war finished in May 2009 and attained 9.1\% in 2012, but again in 2013 fell to 3.4\% and only marginally improved to $4.5 \%$ in 2014.These fluctuations of GDP growth rate were mainly caused due to the direct effects of consumer price index, gross domestic saving, money supply, government expenditure, exchange rate, exports prices of imports, interest rate, tax revenue etc. on gross domestic product due to the unstable circumstances of the country. 
Reaching sustainable fast economic growth is the objective of most countries. It has been a difficult to reach such objective due to many issues that affects economic growth. This study mainly examines the relation of GDP with CPI and GDS, as these associations are some of the important macroeconomic controversies which still on debates among the policy makers and economists to be build up some better economic strategy. The CPI measures the average price changes in goods and services purchased by the consumers over a period of time which has two primary inputs, prices and expenditure weights. As defined by the economists, CPI is a proxy of inflation and was illustrated that high level of inflation leads the GDP of a country to an unstable market economy. Besides the CPI, GDS also contributes in a country's economic growth in a huge scale. The growth of fixed investment can only be potential through adequate savings. Developing countries are always controlled by inadequate savings and investment (Jagadeesh, 2015). Financial savings generates capital establishment and it further results in technical innovation and progress which facilitates with the economies of large-scale production and increases specialization, which eases to accelerate the productivity of labour, it in addition resulting multiplied GDP. Thus savings leads to complete utilization of available rare assets in an effective way, growth in the size of national output, income and employment, thus resolving the complications of inflation, unemployment and balance of payment, poverty, inequality; and making the economy unrestricted from the burden of overseas debt and leads to government of healthier welfare.

The basis behind this study is to empirically check the impact of CPI and GDS on the GDP of Sri Lanka. The remaining part of this paper is structured into four sections: next section deal with review of literatures, section threereport the data and econometrics methodologies, section four specifies the empirical results, whereas section five deliver the conclusion and recommendation sketch from the study.

This research paper composed into five sections. Review of literatures are given in section 2, in section 3 methodologies of the paper are illustrated. Empirical results and discussions are given in sections 4, further conclusions are given in section 5 .

\section{Review of Literature}

Several researches have been carried out on the topic of economic growth using cointegrated approach and the impact of numerous factors to the economic growth by many economists nationally as well as internationally. These all are different from each other either from country to country, period of time, selection of sample size and preference of variables.

Mahmoud (2015) attempted to examine the association between Consumer price index (CPI) and Gross domestic product (GDP) in Mauritania. The data set contains annual time series observations during the period of 1990-2013. It was considered that GDP as the dependent variable and CPI as the independent variable. Ordinary Least Square (OLS) and Granger Causality Test Model were employed to obtain the empirical evidences. The stationarity of variables was examined using Augmented Dickey-Fuller Test (ADF) and the variables were found to be stationary at first difference at $5 \%$ significance level. A positive and significant relationship between the GDP and CPI was revealed by OLS Test. Apart from that Granger Causality Test was applied to verify the causal relationship between two variables and the findings indicate unidirectional causality running from Inflation to economic growth. The most significant policy proposal of this conclusion is that intensive action must be made by Mauritanian government to report the issues which are lead to arise of price level (inflation).

Jagadeesh(2015) investigated the impact of savings in Economic growth in Botswana. To check the existence of a long run relationship between Gross Domestic Product and Gross Domestic savings in Botswana, DOLS approach and an Auto Regressive Distributed Lagged (ARDL) model by Pesaran, Shin and Smith (1999) was employed by considering GDP as the dependent variable. The time series data over a period of 1980 to 2013 was chosen for this study and the results of stationarity and cointegration tests suggested a significant relationship among saving and Economic growth and the study supported Harrod Domar growth Model.Tang and Chua (2009) examined the nexus between savings and growth in Malaysia by via the nonparametric cointegration approach. Quarterly data from 1991 to 2006 was implied and the result of the nonparametric cointegration test illustrates that there is a cointegration association exist between savings and economic growth. Additionally, the multiple rank F-test indicates a bidirectional causality between savings and economic growth. Dynamic OLS is implemented and the estimated result suggests that a positive association between savings and economic growth available in the long run.

Stanner (1993) examined the impact of inflation on economic growth and established the existence of inflation growth relationship in the background of South Asian countries. The study has used the time series data for the period 1980-2012. The study found that there is high positive correlation exist between inflation and economic growth for all the countries. The cointegration result suggest that there is long run relationship exist for Malaysia. However, the rest of the countries have no long run relationship between inflation and economic growth. In order to know the short run dynamics and direction of causality the study used Error Correction and Granger causality test. The study also employed unidirectional VAR analysis to know the short run dynamics between inflation and economic growth.

Seth and Nathan(2015) tested the connection between economic growth and inflation in Tanzania. The study deals with a period from 1990 to 2013 on the basis of annual time series. The second logarithmic differences of Consumer Price Index(CPI) is used to measure inflation and the second logarithmic differences of real GDP per capita as a measure of economic growth. Time series analysis including stationary tests, co-integration tests, Granger causality tests and vector autoregressive analysis (VAR) are applied. The study discovers no co-integration between inflation and economic growth thus no steady long-run equilibrium relationship exists between the variables. But, the VAR analysis exposes that inflation oflag three is significantly and negatively influences economic growth in the short-run. The study additionally indicates 
that there is directional Granger causality between inflation and economic growth. Eventually, the study concludes that inflation has a negative relationship with economic growth as well as with capital accumulation.

Makuria(2014) assessed the relationship between inflation and economic growth in Ethiopia using quarterly data from 1992 to 2010. Based on the Engle-Granger and Johansen co-integration tests it is established that there is a positive long-run relationship between inflation and economic growth. The error correction models illustrate that in cases of shortrun disequilibrium, the inflation model adjusts itself to its long-run path correcting approximately $40 \%$ of the inequity in each quarter. The estimated threshold model recommends $10 \%$ as the optimum level of inflation that simplifies growth.

\section{Methodology}

The progression started with a supplementary systematic accurate collection and analysis of data. The secondary data collection method was used for this study. Annual time series data on GDP (in current U.S. dollars), CPI (base year = 2010), and GDS (in current U.S. dollars) over the period of 1960 to 2016 were obtained from World Development indicators of World Bank National Accounts Data (WBI - 2016) to explain the influence of the explanatory variables such as CPI and GDS on the dependant variable GDP. Since the confirmation procedure is faster and the consistency of data and conclusion is significantly improved, the secondary data was used for the analysis. The method and variables for the current study have been selected with attention of their comparative importance on theoretical and empirical basis. These variables were chosen because of their validity in experiential literature on economic growth and the fact that the government and local strategy argument habitually rotates about them.

However, before the estimation of the specified long-run and the short-run relationship among the variables, the time series properties of the variables of interest were first explored to eliminate any trend element that could lead to spurious parameter estimates. The computer software used was E-Views (version 9) and Minitab (version 16).

\subsection{Model Specification}

The aim of this current study is to analyse the causal relationship of the selected macroeconomic variables with economic growth of Sri Lanka. For that persistence, the following model was adopted from the previous studies. Once taking natural logarithm, these series have been used in this study as GDP $\ln (\mathrm{GDP}), \mathrm{CPI} \ln (\mathrm{CPI})$ and GDS $\ln (\mathrm{GDS})$ (Ahmad, 2012).

$\ln (\mathrm{GDP})=\mathrm{f}\{\ln (\mathrm{CPI}), \ln (\mathrm{GDS})\} \ldots \ldots \ldots \ldots \ldots \ldots \ldots \ldots \ldots \ldots \ldots$

The empirical equation is:

$\ln (\mathrm{GDP})_{\mathrm{t}}=\alpha_{0}+\alpha_{1} \ln (\mathrm{CPI})_{\mathrm{t}}+\alpha_{2} \ln (\mathrm{GDS})_{\mathrm{t}}+\varepsilon_{\mathrm{t}} \ldots \ldots \ldots \ldots \ldots$

Where:

$\ln ($ GDP $)=$ Logarithm of Gross Domestic Product

$\ln (\mathrm{CPI})=$ Logarithm of Consumer Price Index based on year 2010 prices

$\ln ($ GDS $)=$ Logarithm of Gross Domestic Saving

$\alpha_{0}=$ Constant Term

$\mathrm{t}=$ Time Trend

$\varepsilon=$ Random Error Term

\subsection{Estimation Procedures}

Entire analysis of the existing research study, measurements comprise descriptive statistics and correlation statistics, econometric tools comprise Augmented Dickey Fuller (1981) unit root tests both at levels and 1st differenced, Johansen cointegration test, vector error correction model and Granger pair wise causality test have been employed.

\subsubsection{Unit Root Test}

Researchers have improved a variety of tools to examine the order of integration between variables. In this study one important test of those tools were implied, is Augmented-Dickey-Fuller (ADF) test procedure. This test is essential in order to avoid spurious regression which is a common issue when estimating a regression line with data whose generated procedure follows a time trend. The null hypothesis for checking the autoregressive unit root test is 'series has unit root'. The unit root test requires estimating an equation of the form:

$\Delta \mathrm{y}_{\mathrm{t}}=\beta_{0}+\beta_{1} \mathrm{y}_{\mathrm{t}-1}+\gamma_{\mathrm{t}}+\sum_{\mathrm{i}=1}^{\mathrm{k}} \mathrm{A}_{\mathrm{i}} \Delta \mathrm{y}_{\mathrm{t}-\mathrm{i}}+\varepsilon_{\mathrm{t}} \ldots \ldots \ldots \ldots \ldots \ldots \ldots$.

Where:

$\beta_{0}$ is a constant, $\gamma$ is the coefficient on a time trend series, $\beta_{1}$ coefficient of $y_{t-1}, k$ is the order of autoregressive process, $A_{i}$ is a measure of leg length, $\Delta y_{t}=y_{t}-y_{t-1}$ is first difference of $y_{t}, y_{t-1}$ is lagged value of order one of $y_{t}, \Delta y_{t-i}$ are changes in lagged values and $\varepsilon_{\mathrm{t}}$ is the white noise.

\subsubsection{Johansen Cointegration Test}

Cointegration is an econometric method for testing the long run relationship between non-stationary time series variables. If two or more series are themselves non-stationary, but a linear combination of them is stationary, then the series are said to be cointegrated. Cointegration is an equilibrium relationship between time series that individually aren't inequilibrium and it's useful because it allows us to incorporate both short-term dynamics and long-run expectations. The cointegration requires the error term in the long-run relation to be stationary. The superior test for co integration is Johansen's test. This is a test which has all desirable statistical properties. This test permits more than one co integrating relationship. 
$X_{t}=\mu_{1} X_{t-1}+\mu_{2} X_{t-2}+\ldots \ldots . . .+\mu_{\rho} X_{t-\rho}+U_{t}$.

Where, $X_{t}$ is the $(3 \times 1)$ vector,$\mu_{i}$ is the estimated coefficientsand $U_{t}$ is a $(3 \times 1)$ vector of residuals.

\subsubsection{Vector Error Correction Model}

This is a restricted vector autoregressive (VAR) designed for use with stationary series that are known to be cointegrated. If cointegration has been detected between series, we know that there exists a long-run equilibrium relationship between them so we apply VECM in order to evaluate the short run properties of the cointegrated series. The equation form for VECM is as follows:

$\Delta X_{t}=\omega_{1} X_{t-1}+\omega_{2} X_{t-2}+\ldots \ldots \ldots+\omega_{\rho-1} X_{t-(\rho-1)}+\varphi X_{t-1}+U_{t} \ldots \ldots \ldots$.

Where, $\Delta$ is the difference operator The VECM has information about the short-run and long-run adjustment to changes in $X_{t}$, via the estimated parameter $\mu_{\mathrm{i}}$. Here, $\varphi \mathrm{X}_{\mathrm{t}-1}$ is the error correction term and $\varphi$ can be factored into two separate matrices $\alpha$ and $\beta$ such as $\varphi=\alpha \beta^{\prime}$ where $\beta^{\prime}$ denotes the vector of integrating parameters while $\alpha$ is the vector of error-correction coefficients measuring the speed of convergence to the long-run steady state.

$\omega_{i}=\left(I-\mu_{1}-\mu_{2}-\ldots \ldots . . .-\mu_{\rho}\right) ;(I=1,2, \ldots . ., \rho-1)$ and $\varphi=-\left(I-\mu_{1}-\mu_{2}-\ldots . .-\mu_{\rho}\right)$

\subsubsection{Granger Causality Test}

Granger causality test is compassionate to find out the causal relationship with causality movement from economic growth (GDP) to CPI and GDS distinctly.

$\mathrm{Y}_{\mathrm{t}}=\beta_{0}+\sum_{\mathrm{i}=1}^{\mathrm{p}} \beta_{\mathrm{i}} \mathrm{Y}_{\mathrm{t}-\mathrm{i}}+\sum_{\mathrm{j}=1}^{\mathrm{q}} \mathrm{r}_{\mathrm{j}} \mathrm{X}_{\mathrm{t}-\mathrm{j}}+\mathrm{e}_{1} \ldots \ldots \ldots \ldots \ldots \ldots . . . . .$.

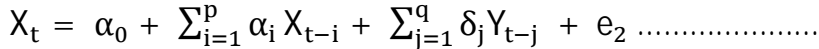

Here, $\mathrm{Y}_{\mathrm{t}}$ and $\mathrm{X}_{\mathrm{t}}$ are the variables, $\mathrm{e}_{1}$ and $\mathrm{e}_{2}$ are the mutually independent error terms. This was applied on the three variables (GDP, CPI, and GDS) taken two at a time, to check for causality and its direction among the variables

\section{Empirical Results and Discussion}

\subsection{Graphical Representation of Stationarity of Variables}

All the variables were transformed into the natural logarithm values themselves to remove the heteroscedasticity issues in the model. Before build an association among the variables, their stationarity patterns were analysed and observed through both the time series plots of the variables and $\mathrm{ADF}$ unit root test. The movements of the three variables (GDP, CPI, and GDS) were graphically presented in Figure 1.

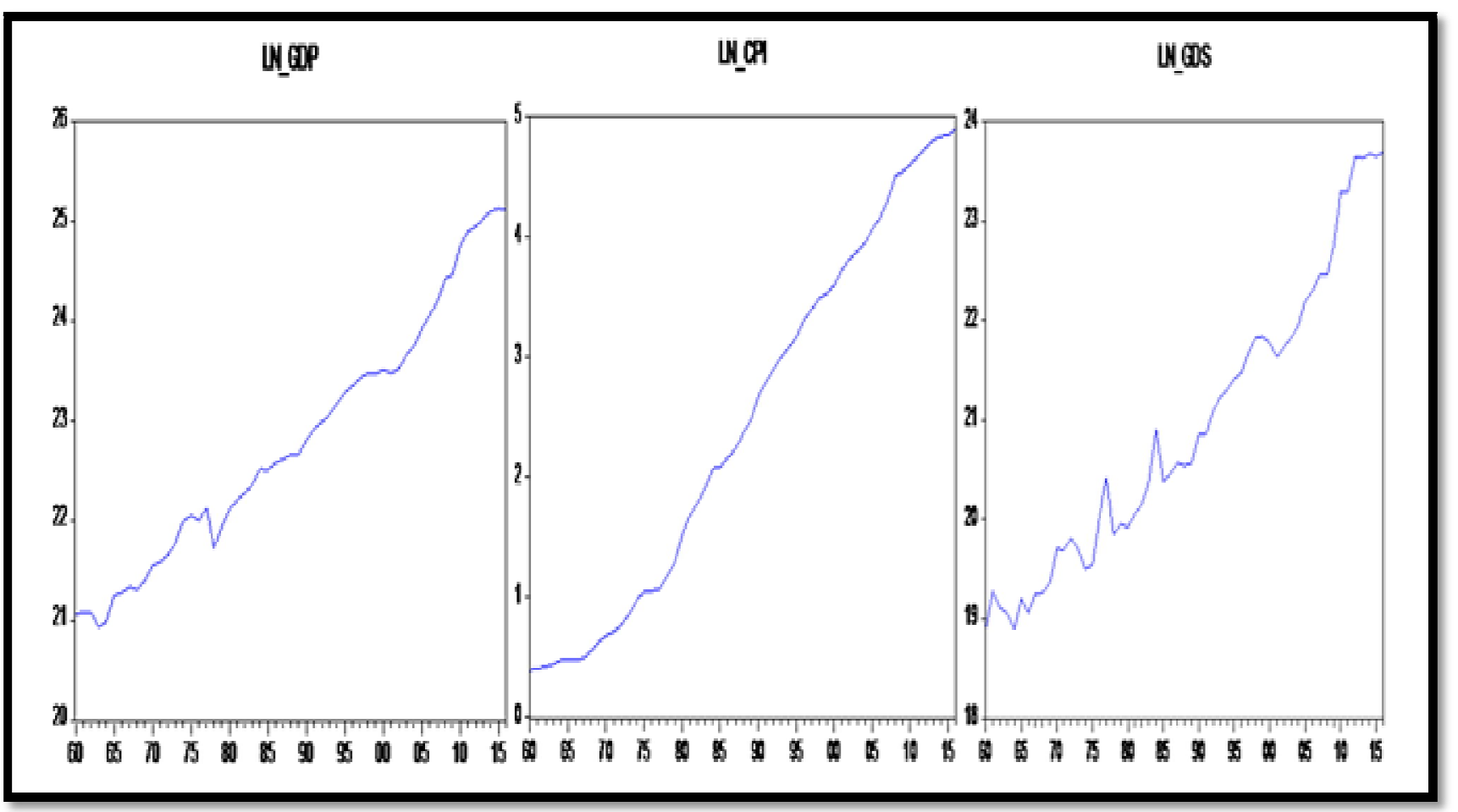

Figure 1: Ln(GDP),Ln(CPI) and Ln(GDS) of Sri Lanka 1960-2016(Yearly)

Figure 1 illustrate that all three variables show an upward trend with an intercept at their level. These series show indication of unit root as the graph of the different variables plotted above failed to cross the zero-line with large withdrawal from it. 


\subsection{Correlation Statistics}

Since one of the core requirements for performing VEC model is that the involved data should be stationary, it was important to check the correlation between the variables as it a statistical procedure to quantify and describe the strength and direction of the relationship between two variables, which have been represented in Table 1.

\begin{tabular}{|c|c|c|c|}
\hline $\ln$ (GDP) & 1 & & \\
\hline $\ln$ (CPI) & 0.9857 & 1 & \\
\hline $\ln$ (GDS) & 0.9925 & 0.9771 & 1 \\
\hline
\end{tabular}

Table 1: Correlation Statistics

\begin{tabular}{|c|c|}
\hline Variables & VIF \\
\hline $\ln (\mathrm{CPI})$ & 3.4 \\
\hline $\ln (\mathrm{GDS})$ & 1.2 \\
\hline
\end{tabular}

Table 2: Variance Inflation Factor

The correlation statistics test consequences revealed that economic growth of Sri Lanka $\{\mathrm{n}(\mathrm{GDP})\}$ is highly positively associated with both CPI $\{\mathrm{n}(\mathrm{CPI})\}$ and GDS $\{\mathrm{n}(\mathrm{GDS})\}$, which is statistically significant at 5 per cent level. The table 2 show that the variance inflation factor values of the independent variables. All the VIF values are less than 5 . It displays that the independent variables are not correlated among them.

\subsection{Unit Root Test}

ADF test was run on the series to determine the number of times we differentiated our non-stationary time series to convert stationary, thus which the results are offered in Table 3, that all the variables are integrated at order one.

\begin{tabular}{|c|c|c|c|}
\hline \multirow{2}{*}{ Variables } & \multicolumn{2}{|c|}{ P - Value } & \multirow{2}{*}{ Result } \\
\cline { 2 - 3 } & Level & First Difference & \\
\hline $\ln (\mathrm{GDP})$ & 0.4387 & $0.0000^{* * *}$ & $\mathrm{I}(1)$ \\
\hline $\ln (\mathrm{CPI})$ & 0.1846 & $0.0063^{* * *}$ & $\mathrm{I}(1)$ \\
\hline $\ln (\mathrm{GDS})$ & 0.2674 & $0.0000^{* * *}$ & $\mathrm{I}(1)$ \\
\hline
\end{tabular}

Table 3: ADF Stationary Test Result (ADF Statistics with Intercept and Trend)

Note: ***,** and * Denotes Significance at $1 \%, 5 \%$ and $10 \%$ Level, Respectively

\subsection{Leg Length Selection Process}

The optimal lag length is important for analysing unit root tests, vector error correction model and causality test. The very commonly systematically employed information criteria are the sequential modified LR test statistic (each test at 5\% level), Final prediction error, and Akaike Information Criterion (AIC). For selection of optimal lag length (lesser the value, better the model) maximum lag order 2 has been estimated. The outcomes are tabularized in the Table 2.

\begin{tabular}{|c|c|c|c|}
\hline Lag & LR & FPE & AIC \\
\hline 0 & NA & $8.82 \mathrm{e}-07$ & -5.427510 \\
\hline 1 & 15.30515 & $9.07 \mathrm{e}-07$ & -5.400237 \\
\hline 2 & $18.58278^{* *}$ & $8.54 \mathrm{e}-07 * *$ & $-5.464588^{* *}$ \\
\hline 3 & 6.195352 & $1.05 \mathrm{e}-06$ & -5.269043 \\
\hline
\end{tabular}

Table 1: Optimal Lag Selection

Note: ** Indicates the Lag Order Selected by the Criterion

\subsection{Johansen Cointegration Test Results}

Once the series may be made stationary by using first difference, they can be used in regression analysis by applying the cointegration technique, which shows the long run relationship among the variables. Table 5 suggested that there exists log run relation among variables. Only Maximum eigenvalue statistics shows one cointegration equation at 5 $\%$ level of significance. 


\begin{tabular}{|c|c|c|c|c|}
\hline \multicolumn{5}{|c|}{ Unrestricted Cointegration Rank Test (Trace) } \\
\hline $\begin{array}{c}\text { Hypothesized } \\
\text { No. of CE(s) }\end{array}$ & Eigenvalue & $\begin{array}{c}\text { Trace } \\
\text { Statistic }\end{array}$ & $\begin{array}{c}\mathbf{0 . 0 5} \\
\text { Critical Value }\end{array}$ & Prob.** \\
\hline None* & 0.389007 & 29.41274 & 29.79707 & 0.0553 \\
\hline At most 1 $*$ & 0.049246 & 2.808551 & 15.49471 & 0.9749 \\
\hline At most 2* & 0.001509 & 0.081554 & 3.841466 & 0.7752 \\
\hline \multicolumn{2}{|c|}{ Unrestricted Cointegration Rank Test (Maximum Eigenvalue) } \\
\hline $\begin{array}{c}\text { Hypothesized } \\
\text { No. of CE(s) }\end{array}$ & Eigenvalue & $\begin{array}{c}\text { Max Eigen } \\
\text { Statistic }\end{array}$ & $\begin{array}{c}\mathbf{0 . 0 5} \\
\text { Critical Value }\end{array}$ & Prob.** \\
\hline None* & 0.389007 & 26.60419 & 21.13162 & 0.0077 \\
\hline At most 1* & 0.049246 & 2.726997 & 14.26460 & 0.9633 \\
\hline At most 2* & 0.001509 & 0.081554 & 3.841466 & 0.7752 \\
\hline
\end{tabular}

Table 2: Johansen Cointegration Test Result (Lag Length $=2$ ) Trace Test Indicates No Cointegration at the 0.05 Level

* Denotes Rejection of the Hypothesis at the 0.05 Level **Mackinnon-Haug-Michelis (1999) P-Values

Max-Eigenvalue Test Indicates 1 Cointegrating Eqn(S) at the 0.05 Level

* Denotes Rejection of the Hypothesis at the 0.05 Level **Mackinnon-Haug-Michelis (1999) P-Values

4.6. Vector Error Correction Model

The obtained results of cointegration test demonstrate that all the series are cointegrated with one cointegrating equations. Therefore, unrestricted vector autocorrelation model is not appropriately supportive. Thus, vector error correction (VECM) model grounded on AIC usinglag length 2 was implied for this model as per the requirement. The result and magnitude of the coefficients of the cointegrating equation regulate the response of each variable in the model to unusual from the long-run relationship. The test results explain t-statistics with lag length 2 (Table 6) and postulate that there is a long-run causality running from GDP to CPI and GDS, which is statistically significant.

\begin{tabular}{|c|c|c|c|}
\hline Error Correction & D\{InGDP\} & $\mathrm{D}\{\operatorname{lnCPI}\}$ & D\{InGDS\} \\
\hline CointEq1 & -0.167157 & 0.075824 & 0.873308 \\
\hline Std. Error & $(0.15710)$ & $(0.07191)$ & $(0.26604)$ \\
\hline t- Statistics & {$[-1.06400]$} & [ 1.05436$]$ & [ 3.28265] \\
\hline $\mathrm{D}\{\operatorname{ngDP}(-1)\}$ & -0.021535 & -0.047788 & -0.730092 \\
\hline Std. Error & $(0.18761)$ & $(0.08588)$ & $(0.31770)$ \\
\hline t- Statistics & [-0.11479] & {$[-0.55644]$} & [-2.29803] \\
\hline $\mathrm{D}\{\operatorname{lnGDP}(-2)\}$ & 0.195751 & -0.185242 & 0.230370 \\
\hline Std. Error & $(0.19072)$ & $(0.08730)$ & $(0.32296)$ \\
\hline t- Statistics & [ 1.02640$]$ & [-2.12187] & [ 0.71331] \\
\hline $\mathrm{D}\{\operatorname{lnCPI}(-1)\}$ & 0.317772 & 0.429287 & -0.637751 \\
\hline Std. Error & $(0.31202)$ & $(0.14283)$ & $(0.52838)$ \\
\hline t - Statistics & [ 1.01844] & [ 3.00559] & {$[-1.20700]$} \\
\hline $\mathrm{D}\{\operatorname{lnCPI}(-2)\}$ & 0.518915 & 0.063562 & 0.546304 \\
\hline Std. Error & $(0.33726)$ & $(0.15438)$ & $(0.57112)$ \\
\hline t - Statistics & [ 1.53862$]$ & [ 0.41171] & [ 0.95655] \\
\hline $\mathrm{D}\{\mathrm{ngDS}(-1)\}$ & -0.117231 & 0.008397 & 0.202279 \\
\hline Std. Error & $(0.09960)$ & $(0.04559)$ & $(0.16866)$ \\
\hline t- Statistics & [-1.17704] & [ 0.18417] & [ 1.19933] \\
\hline $\mathrm{D}\{\operatorname{lnGDS}(-2)\}$ & -0.187136 & 0.034703 & -0.035858 \\
\hline Std. Error & $(0.09105)$ & $(0.04168)$ & $(0.15419)$ \\
\hline $\mathrm{t}$ - Statistics & {$[-2.05525]$} & [ 0.83261] & {$[-0.23256]$} \\
\hline $\mathrm{C}$ & 0.018993 & 0.055988 & 0.116470 \\
\hline Std. Error & $(0.03551)$ & $(0.01625)$ & $(0.06012)$ \\
\hline t- Statistics & [ 0.53494] & [ 3.44485] & [ 1.93714$]$ \\
\hline R-squared & 0.181334 & 0.312661 & 0.414623 \\
\hline Adj. R-squared & 0.056755 & 0.208066 & 0.325543 \\
\hline
\end{tabular}

Table 3: Vector Error Correction Model Estimates

Whilst this study considers economic growth of Sri Lanka as a dependent variable and CPI and GDS as independent variables, the error correction model is:

$\mathrm{D}(\operatorname{lnGDP})=-0.167157\{\ln$ GDP(-1)-0.007193ln $\mathrm{CPI}(-1)-0.852421 \ln G D S(-1)-4.966631\}$

$-0.021535 \mathrm{D}(\operatorname{lnGDP}(-1))+0.195751 \mathrm{D}(\operatorname{lnGDP}(-2))+0.317772 \mathrm{D}(\operatorname{lnCPI}(-1))$

+0.518915 D(lnCPI(-2))- 0.117231 D(lnGDS(-1)) - $0.187136 \mathrm{D}(\ln \mathrm{DDS}(-2))+0.018993$ 
The speed of adjustment or error correction termstates the speed with that the model proceeds to equilibrium following an external disturbance. The negative sign of the coefficient of error correction demonstrate a movement towards equilibrium while a movement away from equilibrium is indicated by a positive sign. As of the above analysis, the results display a significant error correction coefficient with a negative sign and negativity justifies its significance. Therefore, any deviations from the long-run equilibrium could be corrected effectively because of that negative sign. The coefficient of ECM is -0.167157 which indicates that the speed of adjustment to long run equilibrium is $16.72 \%$ sense that is when any past deviation would be corrected in the present period. This implies that the present value of GDP adjusts slowly to changes in CPI and GDS. In other words, there is a long run causality running from CPI and GDS to GDP.

\begin{tabular}{|c|c|c|c|}
\hline \multicolumn{4}{|c|}{ Equation : GDP and CPI } \\
\hline Test Statistics & Value & $\mathrm{df}$ & Probability \\
\hline F - statistics & 2.608427 & $(2,46)$ & 0.0845 \\
\hline Chi - square & 5.216854 & 2 & 0.0737 \\
\hline \multicolumn{4}{|c|}{ Equation : GDP and GDS } \\
\hline Test Statistics & Value & $\mathrm{df}$ & Probability \\
\hline F - statistics & 2.173741 & $(2,46)$ & 0.1253 \\
\hline Chi - square & 4.347482 & 2 & 0.1138 \\
\hline
\end{tabular}

Table 4: Short-Run Causality under VECM (Wald Test)

Then short-run associations are revealed by the coefficients on the lagged differenced terms by using Wald statistic. Table 7 demonstrates that there is no short - run causality running from GDP to inflation and GDP to GDS.

\subsection{Pairwise Causality Results}

Granger causality test is supportive to find out the causal relationship with causation movement from GDP growth rate to $\mathrm{CPI}$ and GDS.

\begin{tabular}{|c|c|c|c|c|}
\hline Null Hypotheses & Obs. & F - stat & Prob. & \multirow{3}{*}{$\begin{array}{c}\text { No } \\
\text { Causality }\end{array}$} \\
\hline $\ln (\mathrm{GDP})$ does not Granger Cause $\ln (\mathrm{CPI})$ & \multirow{2}{*}{55} & 0.25885 & 0.7730 & \\
\hline $\ln (\mathrm{CPI})$ does not $\mathrm{G}$ & & 3.02679 & 0.0574 & \\
\hline $\ln$ (GDS) does not Granger Car & \multirow{2}{*}{55} & 0.811 & 0.4501 & \multirow{2}{*}{$\begin{array}{c}\text { Uni- } \\
\text { directional }\end{array}$} \\
\hline $\ln (\mathrm{GDP})$ does not Granger Cause $\ln (\mathrm{GDS})$ & & 15.1573 & 7.E-06* & \\
\hline
\end{tabular}

Table 5: Pairwise Granger Causality Test Result (Lag Length=2)

The Granger causality test result in Table 8 shows the existence of a uni-directional causality that runs from GDP to GDS and there is no feed-back mechanism. The decision on the direction of causality was made from the probability values of the tests(p-value <0.05). This result is reliable with the former studies(Mohan, 2006).

\subsection{Result of Model Adequacy}

Breusch-Godfrey Serial Correlation LM Test result specifies that there is no serial correlation because the probability of observed R-square is more than 0.05 .

\begin{tabular}{|c|c|c|c|}
\hline \multicolumn{4}{|c|}{ Breusch-Godfrey Serial Correlation LM Test } \\
\hline $\begin{array}{c}\text { F-statistic } \\
\text { Obs*R-squared }\end{array}$ & $\begin{array}{l}1.563715 \\
3.583501\end{array}$ & $\begin{array}{c}\text { Prob. F }(2,44) \\
\text { Prob. Chi-Square(2) }\end{array}$ & $\begin{array}{l}0.2208 \\
0.1667^{*}\end{array}$ \\
\hline \multicolumn{4}{|c|}{ Heteroskedasticity Test: ARCH } \\
\hline $\begin{array}{c}\text { F-statistic } \\
\text { Obs*R-squared }\end{array}$ & $\begin{array}{l}0.627469 \\
1.298514\end{array}$ & $\begin{array}{c}\text { Prob. F }(2,49) \\
\text { Prob. Chi-Square(2) }\end{array}$ & $\begin{array}{l}0.5382 \\
0.5224^{*}\end{array}$ \\
\hline \multicolumn{4}{|c|}{ Empirical Distribution Test for Residuals } \\
\hline Method & Value & Adj.Value & Probability \\
\hline $\begin{array}{l}\text { Anderson-Darling } \\
\text { (A2) }\end{array}$ & 0.351922 & 0.357082 & $0.4556 *$ \\
\hline
\end{tabular}

Table 6: Result of Test of Residuals

ARCH test result concerning heteroskedasticity confirms that the residuals are homoscedastic and AndersonDarling test result indicates that the residuals are normal since probability is more than 0.05 .

\section{Conclusion}

This study examined the causal relationship between gross domestic product, consumer price index (base year= 2010), and gross domestic saving during the period 1960 to 2016of Sri Lanka and employed the ADF unit root test for checking the stationarity of variables, co-integration test, Granger-Causality test and Model adequacy test techniques. 
Correlation statistics suggests that economic growth of Sri Lanka is highly positively correlated significantly with CPI and GDS under the study and the VIF estimates confirm that the explanatory variables are independent. ADF unit root test results demonstrate that the time series data are not stationary at levels but after altering the data into 1st difference, it became stationary. The cointegration test consequences confirm that there is an association among the three macroeconomic variables in the long-run in the same order, which signifies that selected variables follows a random walk theory. Since it was found to be one cointegration equation exists thus, vector error correction model test was employed and the results show that there exists a long-run causality significantly from economic growth to CPI and GDS with 0.167157 speed of adjustment towards equilibrium but wild test results points out that there is no short-run causality from economic growth to CPI and economic growth to GDS. Lastly, pairwise causality test results validate there exists a unidirectional causality that runs from economic growth to gross domestic saving. The results of model adequacy persistthat the residuals are homoscedastic, normally distributed and there is no serial correlation among residuals which confirms that the model is well adequate. Since almost all the variables follow the random walk model, therefore, markets are more or less efficient and in this condition economic growth of Sri Lanka might be improved if both CPIand GDS are controlled ina significant routine.

These results validate that there are important opportunities for Sri Lankan government to revise their economic policy, in terms of inflation (CPI) and GDS. The findings of the empirical studies offer a few directions for Sri Lankan government and policymakers on the consequence of keeping low inflation and reduced total consumption in the present condition of Sri Lankan economy as the increase in the final total consumption causes the negative effect on GDS. Therefore, a healthier management of total final consumption expenditures will lead to a better economic growth.

\section{References}

i. Ahmad, N. a. J. U. T. S., 2012. The relationship between inflation and economic growth in Pakistan: An econometric approach. Asian Journal of research in business economics and management, 2(9), pp. 38-48.

ii. Behera, J., 2014. Inflation and its impact on economic growth: Evidence from six South Asian countries. Journal of Economics and Sustainable Development, 5(7), pp. 145-154.

iii. Dickey, D. A. and Fuller, W. A., 1981. Likelihood ratio statistics for autoregressive time series with a unit root. Econometrica: Journal of the Econometric Society, pp. 1057-1072.

iv. Engle, R. F., and Granger, C. W., 1987. Co-integration and correction : Representation, estimation and testing. Econometrica: Journal of the Econometric Society, pp. 251-276.

v. Jagadeesh, D., 2015. The Impact of Savings in Economic: An Empirical Study Based on Botswana. International Journal, Volume 10.

vi. Mahmoud, L. O., 2015. Consumer Price Index and Economic Growth: A case study of Mauritania 1990-2013. Asian Journal of Empirical Research, 5(2), pp. 16-23.

vii. Makuria, A. G., 2014. The relaionship between inflation and economic growth in Ethiopia (Doctoral dissertation), s.l.: s.n.

viii. Mohan, R., 2006. Causal relationship between savings and economic growth in countries with different income levels. Economic Bulletin, 5(3), pp. 1-12.

ix. Seth, N., 2015. An Assesment on Relationship between inflation and Economic Growth of Tanzania (Doctoral dissertation), s.l.: s.n.

x. Tang, C. F. and Chua, S. Y., 2009. The savings-growth nexus in Malaysis: Evidence from nonparametric analysis. IUP Journal of Finanace Economics, 7(3/4), p. 83. 